\title{
EXPERIÊNCIA DE VISITANTES COM DEFICIÊNCIA VISUAL NA SALA DE FísICA DO MUSEU DE CIÊNCIAS DA UNIVERSIDADE ESTADUAL DE MARINGÁ ${ }^{1}$ EXPERIENCE of Visual Disabilities IN THE PhySics Room of THE Museum of SCIENCES OF THE STATE UNIVERSITY OF MARINGÁ
}

\author{
Samira Cassote GRANDI ${ }^{2}$ \\ Luciano Carvalhais GOMES ${ }^{3}$
}

\begin{abstract}
RESUMO: este trabalho analisou a experiência museal que visitantes com deficiência visual tiveram em um ambiente de Física num Museu de Ciências. Por experiência museal entende-se o conjunto composto pelas principais emoçôes, sensaçôes, vivências e aprendizagens, resultantes da interaçáo do visitante com os objetos e os discursos presentes no museu. Participaram deste estudo seis alunos do CAE-DV de dois colégios públicos de Maringá. A coleta dos dados foi dividida em três momentos: entrevista semiestruturada pré-visita; observação não-participante durante a visita e entrevista semiestruturada pós-visita. A análise dos dados observacionais fundamentou-se num conjunto categorias já desenvolvidas na literatura. A análise dos dados provenientes das entrevistas semiestruturadas foi fundamentada na Análise Textual Discursiva. Os resultados mostraram que o simples cuidado em fazer com que as explicaçóes dos aparatos pelos monitores fossem acompanhadas pelo toque e manuseio do visitante com deficiência visual foi responsável por permitir uma experiência museal gratificante para os participantes. Ao se sentirem acolhidos pela atenção diferenciada dada nas descriçōes dos experimentos, eles ficaram mais à vontade e ativos nos diálogos que ocorreram durante a visita, despertando o interesse em querer aprender o que foi apresentado em cada experimento.
\end{abstract}

PALAVRAS-CHAVE: Educação Especial. Deficiência Visual. Ensino de Física. Museu.

\begin{abstract}
This paper analyzed the museum experience visually impaired visitors had in the Physics environment of a Science Museum. Museum experience is understood as the set consisting of the main emotions, sensations, experiences and learning, resulting from the interaction of the visitor with the objects and discourses in a museum. Six CAE-DV students from two public schools in Maringá participated in this study. The data collection was divided in three moments: pre-visit semi-structured interview; non-participant observation during the visit and post-visit semi-structured interview. The analysis of the observational was based on a set of categories developed in the literature. The analysis of the data from the semi-structured interviews was based on Discoursive Textual Analysis. The results showed that providing explanations of the apparatuses by the monitors accompanied by the touch and handling of the visually impaired visitor was responsible for a gratifying museum experience by the participants. When they felt welcomed by the differentiated attention given in the descriptions of the experiments, they became more comfortable and active in the dialogues that occurred during the visit, arousing the interest for learning what was presented in each experiment.
\end{abstract}

KEYWORD: Special Education. Visual Impairment. Teaching of Physics. Museum.

\section{INTRODUÇÃo}

Os museus, ao longo do tempo, sofreram algumas modificaçóes, passaram de templos das musas para instituiçóes de guardas, e de locais de guarda para ambientes educativos. Suas características variaram conforme seus objetivos e denominaçóes, como exemplo, temos o museu a céu aberto, museu de arte, museu de ciências, museu de tecnologia, museu de história, ecomuseu, museu biográfico, Exploratorium, entre outros. Aos poucos esses espaços

\footnotetext{
${ }^{1}$ http://dx.doi.org/10.1590/S1413-65382317000300008

${ }^{2}$ Mestranda do Programa de Pós-Graduação em Educação para a Ciência e a Matemática. Centro de Ciências Exatas, Universidade Estadual de Maringá. Maringá, PR, Brasil. samyracassote@gmail.com

${ }^{3}$ Professor do Programa de Pós-Graduação em Educação para a Ciência e a Matemática. Centro de Ciências Exatas, Universidade Estadual de Maringá. Maringá, PR, Brasil. lcgomes2@uem.br
} 
vêm assumindo um papel educacional, destacando-se entre os espaços de educação não formal e ganhando importância como um valioso apoio para a educação formal (SAMPAIO, 2014).

Essa nova posição dos museus tem proporcionado que uma grande diversidade de públicos o visite. Os visitantes com deficiência visual, por exemplo, que sofriam por não poderem ver as obras, ou lerem os textos e etiquetas de identificação, nem perceberem os espaços ao serem visitados, hoje contam com museus que apresentam descrição oral dos objetos, além de textos e etiquetas em braile. Embora ainda há muito que ser feito, essa inovação tem favorecido a inclusão nesses ambientes e proporcionado mais qualidade na experiência museal desse perfil de público. Podemos entender experiência museal como um conjunto composto pelas principais emoções, sensaçôes, vivências e aprendizagens, resultantes da interação do visitante com os objetos e os discursos presentes no museu.

Nos dias atuais, encontramos muitos textos tratando da questão da acessibilidade e da inclusão social, como também estudos sobre a experiência museal (SOUZA; SILVA, 2016), e outras pesquisas que investigam os impactos das exposiçóes, as experiências e as aprendizagens nesses espaços (PRICE et al., 2015 apud SOUZA; SILVA, 2016). No entanto, não encontramos nenhum trabalho que analisasse a experiência museal de visitantes com deficiência visual nos ambientes de Física dos Museus de Ciências.

Portanto, a nossa pesquisa visou contribuir com as pesquisas recentes na área museológica, analisando a temática da experiência museal de visitantes com deficiência visual nos ambientes de Física dos Museus de Ciência. O nosso objetivo principal foi responder ao seguinte questionamento: a experiência de visitantes com deficiência visual na sala de Física do Museu de Ciências da Universidade Estadual de Maringá é afetivamente positiva?

Para responder a essa pergunta, analisamos a visita de seis alunos com deficiência visual. Juntamente com a observação não-participante durante a visita, utilizamos as entrevistas semiestruturadas para a coleta dos dados pré e pós visita. Para nos auxiliar com a análise dos dados obtidos durante a visita, utilizamos um conjunto de categorias desenvolvidas por Allen (2002 apud SAPIRAS, 2007). A análise dos dados provenientes das entrevistas semiestruturadas foi feita seguindo a metodologia da Análise Textual Discursiva de Moraes e Galiazzi (2003). A seguir, descrevemos mais detalhes da metodologia utilizada.

\section{Método}

A pesquisa se desenvolveu após aprovação concedida pelo Comitê de Ética em Pesquisa da instituição e mediante a autorização de todos os participantes. Participaram da pesquisa um público de alunos com deficiência visual do CAE-DV de dois colégios públicos de Maringá.

\subsection{Procedimento para a Coleta de dados}

A coleta de dados se deu por meio de entrevistas semiestruturadas na pré e pós visita e por observação não-participante durante a visita. A entrevista semiestruturada foi escolhida por fazer emergir informaçóes de forma mais livre, na qual as respostas não estão necessariamente condicionadas a uma padronização de alternativas. Segundo Boni e Quaresma (2005), 
a entrevista semiestruturada permite uma combinação entre perguntas abertas e fechadas, a qual o entrevistador tem a possibilidade de discorrer sobre o tema proposto, em um contexto de conversa informal. $\mathrm{O}$ entrevistador deve ficar atento na "[...] discussão para o assunto que o interessa fazendo perguntas adicionais para elucidar questóes que não ficaram claras ou ajudar a recompor o contexto da entrevista, caso o informante tenha "fugido" ao tema ou tenha dificuldades com ele" (BONI; QUARESMA, 2005, p. 75).

Esse tipo de abordagem propicia durante a entrevista uma maior proximidade entre o entrevistador e o entrevistado, gera um tipo de diálogo prazeroso, e com a possibilidade de esclarecer dúvidas ou interpretaçóes que podem surgir durante a entrevista. As entrevistas foram registradas por meio de filmagem e gravação em áudio, sendo transcritas posteriormente.

Durante a visita utilizamos a técnica de observação não-participante, pois “[...] ajuda o pesquisador a identificar e a obter provas a respeito de objetivos sobre os quais os indivíduos não têm consciência, mas que orientam seu comportamento" (MARCONI; LAKATOS, 2007, p.88). Nesse caso, filmamos as apresentaçóes com o intuito de analisar a interaçáo dos visitantes entre si, com os experimentos e com os mediadores da sala de Física.

\subsection{Procedimentos para a ANÁlise dos dados}

Para nos auxiliar na análise dos dados, utilizamos a Análise Textual Discursiva [ATD] proposta por Moraes e Galiazzi (2011). Na aplicação da ATD, há três principais etapas a serem seguidas: a desmontagem dos textos do corpus (unitarizaçáo), estabelecimento de relaçóes entre as unidades de análise (categorização) e o captar do novo emergente (comunicação da nova compreensão por meio de metatextos).

A unitarização corresponde a um ciclo de análises, na qual parte de uma desmontagem dos textos (desconstrução), buscando examinar minuciosamente o corpus e fragmentá-lo em unidades de análise, referentes aos fenômenos em estudo (MORAES, 2003). Esse processo requer uma codificação e nomeação dos dados em unidades estabelecidas. A seguir, apresentamos as unidades de análise da pré e pós visita.

\begin{tabular}{|c|c|c|}
\hline & UNIDADE & NOME \\
\hline \multirow{9}{*}{$\begin{array}{l}\text { Unidades de } \\
\text { análise para a } \\
\text { pré-entrevista }\end{array}$} & I & Ênfase, na escola, em recursos didáticos visuais e orais \\
\hline & II & Visáo acrítica com relaçáo à escola \\
\hline & III & Ênfase, no museu, em recursos didáticos visuais e orais \\
\hline & IV & Visão acrítica com relaçáo ao museu \\
\hline & V & Metodologia mais adequada, na escola, aos que têm deficiência visual \\
\hline & VI & Metodologia mais adequada, no museu, aos que têm deficiência visual \\
\hline & VII & $\begin{array}{l}\text { Oportunidade de compreender alguns fenômenos científicos de modo } \\
\text { diferente }\end{array}$ \\
\hline & VIII & Reviver experiências positivas de visitas anteriores \\
\hline & IX & Receio de reviver experiências negativas de visitas anteriores \\
\hline \multirow{2}{*}{$\begin{array}{l}\text { Unidades de } \\
\text { análise para a } \\
\text { pós-entrevista }\end{array}$} & $\mathrm{X}$ & Lembranças com destaque sobre os objetos \\
\hline & $\mathrm{XI}$ & Lembranças com carga afetiva \\
\hline
\end{tabular}

Quadro 1 - Unidades de análise

Fonte: elaboração própria. 
O processo de categorização consiste em “[...] construir relações entre as unidades de base, combinando-as e classificando-as, reunindo esses elementos unitários na formação de conjuntos que congregam elementos próximos, resultando daí sistema de categorias" (MORAES; GALIAZZI, 2011, p.12). Desse modo, definimos as categorias como apresentadas a seguir:

\begin{tabular}{|c|c|c|}
\hline & CATEGORIAS & NOME \\
\hline \multirow{2}{*}{$\begin{array}{l}\text { Categorização das unidades de } \\
\text { análise da pré-visita }\end{array}$} & $\mathrm{C} 1$ & $\begin{array}{l}\text { Metodologia: destaca as dificuldades metodológicas } \\
\text { encontradas na escola e no museu }\end{array}$ \\
\hline & $\mathrm{C} 2$ & Expectativa: refere-se às expectativas para a visita \\
\hline \multirow{2}{*}{$\begin{array}{l}\text { Categorização das unidades de } \\
\text { análise da pós-visita }\end{array}$} & C 3 & $\begin{array}{l}\text { Conceitual: uma maior presença de elementos conceitu- } \\
\text { ais na fala do entrevistado }\end{array}$ \\
\hline & $\mathrm{C} 4$ & $\begin{array}{l}\text { Afetiva: uma maior presença de elementos afetivos na } \\
\text { fala do entrevistado }\end{array}$ \\
\hline
\end{tabular}

Quadro 2 - Categorização das unidades de análise

Fonte: elaboração própria.

Legenda

C 1: Categoria 1 - Metodologia

C 2: Categoria 2 - Expectativa

C 3: Categoria 3 - Conceitual

C 4: Categoria 4-Afetiva

A terceira etapa da ATD é a construção de metatextos, essa construção é uma característica dessa metodologia. A partir da análise, descrição e interpretação de sentidos e significados de um conjunto de textos ou documentos (corpus), produz-se um metatexto (MORAES, 2003).

Para nos auxiliar na análise das observaçóes durante a visita ao museu, utilizamos um conjunto de categorias e subcategorias desenvolvidas por Allen (2002 apud SAPIRAS, 2007).

\section{Resultados E Discussóes}

Para a nomenclatura das unidades procedemos da seguinte forma: todas as unidades têm em comum a letra "U”, da qual se refere a palavra Unidade, seguida pelo número de cada entrevistado (1 a 10), acrescido pela unidade em algarismos romanos (primeira unidade (I), segunda unidade (II), etc.). Assim, ao olharmos para a unidade U 3.II, podemos dizer que fatores da transcrição da entrevista do E.3 encontra-se presente na segunda unidade (II). Pelo motivo de limitação de páginas do artigo, apresentaremos apenas algumas respostas obtidas nas entrevistas pré e pós visita, bem como alguns diálogos que surgiram durante a visita. Desse modo, por consequência, nem todas unidades de análise serão citadas.

\subsection{Pré-visita: Categoria C1 - Metodologia}

Nesta categoria, apresentamos, por meio das unidades de análise obtidas das respostas dos entrevistados, quais os principais equívocos metodológicos no processo de ensino que 
dificultaram a aprendizagem dos conteúdos básicos do currículo escolar. Em seguida, mostramos como esses equívocos também são responsáveis por desencadearem uma experiência museal frustrante. Por fim, mostramos alguns aspectos metodológicos considerados adequados tanto para o ensino quanto para as apresentaçôes em museus para as pessoas com deficiência visual.

\subsection{1 ÊNFASE, NA ESCOLA, EM RECURSOS DidÁticos VISUAIS E ORAIS (UNIDAdE DE ANÁlISE I)}

As principais dificuldades relatadas pelos entrevistados com relação ao ensino se deve ao quase exclusivo uso de recursos visuais e orais na comunicação pelo professor. Como podemos observar pela fala de E.2 a seguir:

E.2: [...] na minha época, na década de 80, o atendimento pra pessoa com deficiência nas escolas era bem precário, eu aprendi alguma coisa mas sempre faltando algo, não conseguia acompanhar a lousa, o professor não tinha orientação como tem hoje, hoje tem tudo um acompanhamento e naquela época náo tinha nada disso, entâo na maioria das matérias eu tive uma certa dificuldade entáo eu levei um tempo a mais pra compreender. Foi Matemática, exatas, porque geralmente na parte de exatas, a gente tem que conhecer todos os detalhes de uma soma, uma multiplicação tem toda uma regrinha ali que tem que ter uma atençáo especial, e às vezes faltou isso.

Esse cenário só começa a se modificar a partir da década de 90 (século XX) com o surgimento de várias pesquisas mostrando que há problemas na formação de professores para lidar com uma educação inclusiva (DICKMAN; FERREIRA, 2008). No entanto, ainda nos dias hoje, esses problemas permanecem. Por exemplo, os entrevistados E.5 e E.10 citam a dificuldade de compreensão das aulas devido à forte predominância da utilizaçáo de recursos audiovisuais pelo professor:

E.5: As minhas aulas de Física e Química são muito teórica e passam muito no quadro e, como não enxergo no quadro, então dificulta um pouco pra mim ter um entendimento da matéria, entáo eu preciso optar por outros meios para entender o que a professora está falando.

E.10: Olha, Matemática, Química e Física foi por causa da minha dificuldade em questão de adaptação e também por causa dos cálculos.

\subsection{2 ÊNFASE, NO MUSEU, EM RECURSOS DidátICos VISUAIS E ORAIS (UNIDADE DE ANÁLISE III)}

Alguns entrevistados que já tiveram uma experiência museal disseram que os monitores também cometeram os mesmos equívocos metodológicos de seus professores, ou seja, fizeram uso de modo quase exclusivo de recursos visuais e orais na comunicação. Por exemplo, de acordo com E.6:

E.6: Na verdade, foi meio estranho na parte das plantas, porque é muito visual, que eles vão descrevendo e você não pode sentir, e até entendo, tem coisa que não tem como sentir mesmo, e é meio chatinho mesmo.

Ficou evidente, pelas respostas dadas, que os visitantes com deficiência visual esperam que os museus tenham um número adequado de monitores para direcioná-los aos objetos e fazerem as explicaçóes adequadas, podendo usar textos adaptados em braile ou quaisquer outros recursos táteis como maquetes. Também é importante que seja permitido tocar os objetos. 
Assim, é fundamental que os monitores se preparem adequadamente para receberem esse perfil de público.

\subsubsection{Metodologia mais adequada, na escola, AOS QUE TÊM DEFICIÊNCIA VISUAL (UNIDADE DE ANÁLISE V)}

Nos últimos anos, houve uma explosão de novos recursos digitais de comunicação para os alunos com deficiência visual, que tem contribuído para romper com muitas barreiras no ensino. Alguns exemplos desses materiais são: "[...] os softwares nos computadores, impressoras Braile, teclados modificados, software de reconhecimento de voz, etc" (POKER; NAVEGA; PETITTO, 2012, p. 23). Para as pessoas com baixa visão, equipamentos ópticos adaptados podem garantir a independência permitindo-lhes "[...] usar calculadoras, medir pressão arterial, identificar números telefônicos, escrever, ler textos, cozinhar, vestir-se, identificar dinheiro, etc. [...] Através do uso de lentes, lupas, telelupas, software de leitura de tela, impressoras Braile, etc" (ibid, p. 24). Na fala do entrevistado abaixo, fica explícita a boa aceitação que esses recursos metodológicos têm:

E.3: [...] Hoje em dia a tecnologia ajudou bastante, os materiais em braile e deu pra acompanhar normal eu conseguia entender sempre as explicações, as professoras ia lá explicar certinho, tinha bastante material que auxiliava, tinha coisa em relevo, em braile pra ler.

Além dos novos recursos tecnológicos, destaca-se, como um fator positivo nos relatos, a utilização de materiais didáticos táteis, como: figuras, desenhos, cartazes, histórias em quadrinhos, quebra-cabeças, etc. O entrevistado E.6 nos apresenta um exemplo dessas práticas pedagógicas diferenciadas:

E.6: Alguns professores trazia algum material com areia, pra eu sentir.

\subsubsection{Metodologia mais adequada, no MuSeu, aOS QUe têM DeficiênCia VISUAL (UNIDADE DE ANÁlise VI)}

Para os entrevistados, a metodologia mais adequada para apresentar os objetos do museu para um público que tem deficiência visual é aquela que faz uso de explicaçóes detalhadas sobre o que esta sendo mostrado. Utilizando, sempre que possível, de materiais explicativos táteis e permitindo que os visitantes toquem e manipulem os objetos. Vejamos algumas falas dos entrevistados que corroboram essa nossa afirmação:

E.2: Com maior descrição pra gente, pra quem é baixa visão, e no meu caso que é perda total, porque, às vezes, a pessoa não está acostumada a descrever algo pra um deficiente visual e algo passa batido.

E.3: Lá tem todo tipo de material pra explicar pra você em relevo, têm vários experimentos, um às vezes que não pode sentir mas é bem explicadinho, mas têm vários tipos de material que auxilia como exemplo na área da Matemática, da Biologia, é muito interessante essa visita.

\subsection{Pré-Visita: Categoria C2 - Expectativa}

Nesta categoria, destacamos as expectativas dos entrevistados com relação à visita que fariam no ambiente de Física do Museu de Ciências. As unidades de análise distribuídas nesta 
categoria nos permitem ter uma noção mais clara sobre quais aspectos essas expectativas estavam relacionadas. Na nossa análise pós-entrevista, um dos aspectos a ser verificado é saber até que ponto essas expectativas foram satisfeitas, pois, segundo Marandino (2005 apud MORAIS; MAIA; PINTO, 2010), os fatores sociais e as expectativas pessoais dos diferentes visitantes ao ambiente museal, são relaçóes importantes que contribuem para a significação e a valorização que esses darão às experiências vivenciadas nos museus.

\subsubsection{Oportunidade DE COMPREender ALGUNS FENÔMENOS CIENTÍficos DE MODO DIFERENTE (UNIDADE DE ANÁLISE VII)}

Como exemplo para esta unidade de análise, ressaltamos a fala do entrevistado E.5, que manifesta como expectativa a vontade de poder compreender mais sobre alguns conceitos físicos que foram abordados na sala de aula:

E.5: Parte do primeiro ano, quando você solta uma bolinha o tempo que ela leva, ela e outro objeto, essa parte é bem legal.

Os entrevistados também esperavam que o museu abordasse a Física de uma maneira mais dinâmica, mais concreta, por meio de objetos e demonstraçóes, dessa forma, seria possível compreender melhor alguns fenômenos físicos:

E.3: Creio que vai ser igual foi da outra vez, bastante falado, pessoal falando bastante, explicando os materiais, sempre tem uma área que dá pra gente perceber, tocar, fazer os experimentos, tanto na Física quanto na Química. Sempre têm alguns materiais pra gente percebendo, tocando, vendo o relevo. Tudo certinho.

De acordo com os entrevistados, as explicações acerca do objeto devem ser mais detalhadas, de modo a permitirem compreender de forma mais significativa o que está sendo apresentado:

E.3: As explicaçóes bem detalhadas, podendo sentir os materiais e prestando bem atenção nas explicaçóes. Auxilia bastante.

Desse modo, os entrevistados esperavam que os experimentos e conceitos não fossem apresentados na visita do mesmo modo que era feito muitas vezes nas aulas, ou seja, com foco excessivo na visão e audição, sem a complementação de nenhum recurso tátil.

A partir das categorias e unidades de análise da pré-visita, elaboramos o metatexto, apresentado a seguir, intitulado "Saberes docentes para a inclusão do aluno com deficiência visual em aulas de Física”. Esse é o mesmo título dado pelo professor Éder Pires de Camargo em um dos seus livros. Fizemos essa escolha de propósito, pois percebemos, pelas respostas dadas na entrevista semiestrutura da pré-visita, que há uma relação entre os problemas levantados pelos entrevistados com os abordados pelo o autor do livro. 


\subsection{Pré-Visita: Metatexto - Saberes docentes para a inclusão do aluno com DEFICIÊNCIA VISUAL EM AULAS DE FísICA}

Em seu livro, Camargo (2012) faz uma análise, a partir dos resultados de várias pesquisas suas anteriores, sobre quais seriam os saberes docentes necessários para se implementar uma didática inclusiva nas aulas de Física. Entendendo por didática inclusiva:

[...] o conjunto de procedimentos educacionais intencionais adequado ao atendimento da diversidade humana. Em outras palavras, a didática inclusiva orienta-se por saberes organizativos e teórico-práticos cujo objetivo é favorecer a participação efetiva de todos os alunos, com e sem deficiência, em uma determinada atividade educacional (CAMARGO, 2012, p.15).

Em outras palavras, a didática inclusiva procura colocar na prática as recomendaçóes trazidas por Soler (1999) na "Didática Multissensorial das Ciências". Quando nos deparamos com informaçóes como [...] na minha época, na década de 80, o atendimento pra pessoa com deficiência nas escolas era bem precário, não conseguia acompanhar a lousa [...], ou [...] as minhas aulas de Física e Química são muito teórica e passam muito no quadro e, como não enxergo no quadro, então dificulta um pouco pra mim ter um entendimento da matéria [...], entendemos que há ainda um longo caminho a ser percorrido para termos uma educação inclusiva na perspectiva que nos trazem Camargo (2012) e Soler (1999).

Uma das principais dificuldades relatadas por alunos com deficiência visual para acompanhar as disciplinas de exatas é compreender a linguagem matemática utilizada pelos professores. Entre os nossos entrevistados, essa problemática também foi destacada em expressões, como [...] geralmente na parte de exatas, a gente tem que conhecer todos os detalhes de uma soma [...], ou [...] Matemática, Quimica e Física, foi por causa da minha dificuldade em questão de adaptação e também por causa dos cálculos [...]. De acordo com Camargo (2012, p. 260):

Esse tema é pouco discutido na perspectiva da deficiência visual, é muito importante ao ensino de física e representa para discentes cegos ou com baixa visão uma grande barreira a ser superada. Docentes de física dificilmente sabem como lidar com esse tipo de situaçáo. O problema envolve a relação triádica raciocínio/registro/observação dos cálculos. Como o deficiente visual, por utilizar o Braille, não observa simultaneamente o que escreve, a relação é destituída. Em Braille, a escrita ocorre na parte oposta do papel. Assim, para observar durante um cálculo aquilo que está registrando, um deficiente visual precisa retirar o papel da reglete, tatear o que registrou, voltar o papel à posição anterior e continuar o processo. Isso descredencia o Braille, em sua forma original, como alternativa para a realização de procedimentos matemáticos [...].

Desse modo, o autor afirma a necessidade de se desenvolver materiais que possibilite ao aluno com deficiência visual manipular números e variáveis de forma simultânea. Ou seja, que dê condiçóes dele registrar, observar aquilo que registra e raciocinar ao mesmo tempo. Como exemplo de material adequado à realização de cálculos por deficientes visuais, Camargo (2012) cita um que foi criado por Tato (2009). Contudo, além de saber trabalhar com a linguagem matemática para promover a inclusão do aluno com deficiência visual em aulas de Física, Camargo (2012) elenca mais oito saberes: 1. Saber sobre a história visual do aluno; 2. Saber identificar a estrutura semântico-sensorial dos significados físicos veiculados; 3. Saber abordar os múltiplos significados de um fenômeno físico; 4. Saber construir de forma sobreposta registros táteis e visuais de comportamentos/fenômenos físicos de significados vinculados 
às representações visuais; 5. Saber destituir a estrutura empírica audiovisual interdependente; 6. Saber explorar as potencialidades comunicacionais das linguagens constituídas de estruturas empíricas de acesso visualmente independente; 7. Saber realizar atividades comuns aos alunos com e sem deficiência visual e 8. Saber promover interação entre discentes com e sem deficiência visual, utilizando em tal interação os materiais de interfaces tátil-visuais.

De modo resumido, podemos dizer que esses saberes são necessários para o professor ser capaz de discernir o conceito físico que tem significado indissociável de determinada percepção (visão, audição ou tato) daquele que é apenas vinculado a uma, ou outra percepção sensorial. Por exemplo, o significado de cor, transparência e opacidade é indissociável do sentido da visão. A pessoa que é cega de nascimento só poderá saber se um objeto é colorido, opaco ou transparente se alguém falar para ela, não há como descobrir isso com os seus outros sentidos. Nesse caso, a sua compreensão do significado de cor, transparência e opacidade jamais será a mesma da de um vidente. Isso não acontece, por exemplo, com a relação que existe entre comprimento de onda e cor, pois tanto um cego de nascença, quanto um vidente podem compartilhar da mesma compreensão. Desse modo, dizemos que essa relação está apenas, tradicionalmente, vinculada com o sentido da visão, mas não estabelece com esse uma indissociabilidade para ser entendida.

No entanto, segundo Camargo (2012), são poucos os conceitos físicos que têm significados indissociáveis da visão. Desse modo, eles também podem ser compreendidos pelo aluno que possui uma deficiência visual, desde que a prática pedagógica do professor não privilegie apenas o sentido da visão. Mas, segundo os depoimentos dos entrevistados, não é isso o que acontece, por exemplo: [...] para aprender tinha mais dificuldade pra evoluir por que é muito visual, principalmente a Física, o professor faz muito desenho [...], na sequência ele arremata, [...] eles trabalha muito com o visual, e ai é difícil [...].

Diante desse panorama, é claro que quem tem uma deficiência visual sempre elogiará qualquer iniciativa didático-pedagógica diferenciada, que teve o cuidado de complementar as informaçōes visuais com recursos táteis, por exemplo. Desse modo, não podemos nos iludir com alguns relatos de experiências didáticas positivas na escola como [...] as professoras ia lá explicar certinho, tinha bastante material que auxiliava, tinha coisa em relevo, em braile pra ler [...], ou [...] Ele pegou gominhas para entender os gráficos [...], pois, infelizmente, ainda não são ações rotineiras para quem dá aulas para um aluno que tem deficiência visual.

O mesmo podemos dizer para as descriçóes entusiasmadas de algumas visitas realizadas a um museu como [...] lá tem todo tipo de material pra explicar pra você em relevo, têm vários experimentos, um às vezes que não pode sentir mas é bem explicadinho, mas têm vários tipos de material que auxilia como exemplo na área da Matemática, da Biologia, é muito interessante essa visita [...], ou [...] sempre tem uma área que dá pra gente perceber, tocar, fazer os experimentos, tanto na Física quanto na Química. Sempre têm alguns materiais pra gente percebendo, tocando, vendo o relevo [...].

Temos que ter a precaução de não generalizarmos esses depoimentos, acreditando que esses espaços estão preparados para receberem adequadamente esse perfil de público, possibilitando que eles sempre tenham uma experiência museal gratificante, principalmente os museus de ciências. Não é em qualquer ocasião que terão materiais para serem manipulados ou 
monitores preparados adequadamente para atenderem a esse perfil de público. Infelizmente, ainda há muito a ser feito para que isso se transforme em algo natural. É por isso que também tivemos os seguintes relatos: [...] na primeira vez, algumas coisas a gente pegou. Eles mostraram algumas coisas. Eles mostraram os materiais em relação ao peso do chumbo, fomos no giroscópio, foi legal. Mas, nas outras vezes, não aconteceu isso. Não foi planejado antes. A pessoa ficava falando o que tava la mostrando, mas não se focou muito na parte prática de uma pessoa cega tocar, na parte Física, na interaçâo [...]; [...] foi meio estranho na parte das plantas, porque é muito visual, que eles vão descrevendo e você não pode sentir, e até entendo, tem coisa que não tem como sentir mesmo, $e$ é meio chatinho mesmo [...].

Nesse contexto, antes de começarmos a discutir como se dá a aprendizagem desse ou daquele conceito físico por uma pessoa com deficiência visual, temos que nos preocupar se, de fato, está havendo comunicação entre o emissor (professor/monitor) e receptor (aluno/ visitante). Segundo Camargo (2012, p. 43):

Comunicar é tornar comum um mesmo objeto mental (sensação, pensamento, desejo, afeto). Portanto, a comunicaçáo de uma determinada informação ocorrerá na medida em que emissor e receptor tenham condiçôes de compartilhá-la. Esse "compartilhar", todavia, dependerá de dois fatores estruturais, o conhecimento do código por meio do qual a informação é veiculada e as condiçóes de acessibilidade a ele.

Em um primeiro momento, para romper com as barreiras iniciais do processo comunicativo, é importante ouvir as pessoas com deficiência visual, para saber delas, como o emissor vidente pode comunicar determinada informação para elas. Precisamos aprender a nos colocar no lugar do outro. Ao fazermos isso, veremos que o que elas solicitam é relativamente simples de ser feito. Vejamos: [...] maior descrição pra gente, pra quem é baixa visão, e no meu caso que é perda total, porque, às vezes, a pessoa náo está acostumada a descrever algo pra um deficiente visual e algo passa batido [...], [...] Experimentos práticos que você possa vivenciar, menos a parte teórica e mais a parte prática. É como eu disse agora a pouco, que além de ser falado sejam feitas coisas que as pessoas possam bem mais praticar, ter acesso ao toque, a fazer algumas coisas do que só ouvir [...]; [...] Tem que ser em relevo, pra mim passar a mão e tem que falar pra mim, senão eu não sei o que está acontecendo [...]; [...] As explicaçóes bem detalhadas, podendo sentir os materiais e prestando bem atenção nas explicaçóes. Auxilia bastante [...].

\subsection{Durante a Visita}

Durante a visita, analisamos aspectos da interação dos entrevistados no ambiente, seja com os experimentos, com os monitores e entre os demais visitantes, procurando reconhecer em suas falas aspectos que revelem o tipo de experiência que estão sendo vivenciadas, de acordo com as categorias e subcategorias de Allen (2002 apud SAPIRAS, 2007). Os experimentos escolhidos para apresentação foram selecionados com base em seus conceitos físicos e por apresentarem a possibilidade e segurança para o toque, a saber: Banco de Pregos, Berço de Newton, Garrafa de Leyden, Gerador de Van der Graff e Transformador Redutor. Na tabela seguinte, encontra-se o resultado que fizemos das análises das conversas dos visitantes durante a explicação dos experimentos: 


\begin{tabular}{|c|c|c|}
\hline $\begin{array}{l}\text { CATEGORIAS } \\
\text { CONVERSACIONAIS }\end{array}$ & $\begin{array}{l}\text { No DE } \\
\text { CONVERSAS }\end{array}$ & EXEMPLOS \\
\hline Perceptiva de Nomeaçáo: & 3 & E.1 Ah, Bocha!! Bocha pesada \\
\hline Perceptiva de Caracterização & 2 & E.9 Ah, aqui é a correia? \\
\hline Perceptiva de Citaçáo & 1 & $\begin{array}{l}\text { E.2 Pois é, acho que é aquele conjunto de pregos } \\
\text { que da o, como se diz }\end{array}$ \\
\hline conceitual e Inferência Simples & 4 & E.1 Porque a borracha ela é isolada, isola.. \\
\hline $\begin{array}{l}\text { Conceitual de Inferência Com- } \\
\text { plexa }\end{array}$ & 4 & $\begin{array}{l}\text { E.5 A energia. } \\
\text { E.1 Energia estática } \\
\text { E.1 O prego distribui o peso.... }\end{array}$ \\
\hline Conceitual de Prediçáo & 1 & E.2 Humm..eu acho que estoura..não sei \\
\hline Conceitual de Metacognição & 2 & $\begin{array}{l}\text { E. } 2 \text { eu acho que estoura, pela sensibilidade do mate- } \\
\text { rial, acho que estoura }\end{array}$ \\
\hline Conectiva Com a Vida & 5 & E.1 Elétrica! \\
\hline $\begin{array}{l}\text { Conectiva Com Conhecimentos } \\
\text { Prévios }\end{array}$ & 8 & $\begin{array}{l}\text { E. } 8 \text { Ahh...é um imã agora } \\
\text { E.2 Tá dando equilíbrio? }\end{array}$ \\
\hline Afetiva & 7 & $\begin{array}{l}\text { E.1 Que legal (risos) } \\
\text { E.8 Nossaaa.... }\end{array}$ \\
\hline
\end{tabular}

Quadro 3 - Categorias e subcategorias das conversas surgidas durante a visita

Fonte: elaboração própria.

Legenda

E.1: Entrevistado 1

E.2: Entrevistado 2

E.5: Entrevistado 5

E.8: Entrevistado 8

E.9: Entrevistado 9

Da análise das conversas surgidas durante a visita, percebemos que apesar da falta de experiência dos monitores em atender a esse perfil de público, o que gerou muita ansiedade e nervosismo por parte deles, concluímos que o simples cuidado de fazer com que as explicaçóes dos aparatos pelos monitores fossem acompanhadas pelo toque e manuseio do visitante com deficiência visual foi responsável por permitir uma experiência museal gratificante para os participantes. Ao se sentirem acolhidos pela atenção diferenciada dada nas descriçóes dos experimentos, eles ficaram mais à vontade e ativos nos diálogos que ocorreram durante a visita, despertando o interesse em querer aprender o que foi apresentado em cada experimento. O que está em conformidade com o que Piaget (2014) afirma sobre a relação entre a afetividade e a cognição. Os dados analisados a seguir, provenientes da entrevista semiestruturada pós-visita, também confirmarão o que estamos afirmando aqui. 


\subsection{Pós-Visita: Categoria C3 - Conceitual}

Nesta categoria, incluímos as lembranças dos objetos seguidas por uma tentativa de análise conceitual sobre o fenômeno apresentado sem a predominância de uma carga afetiva verbalizada.

\subsection{LEMBRANÇAS COM DESTAQUE SOBRE OS OBJETOS (UNIDAdE DE ANÁLISE X)}

O experimento mais citado pelos visitantes foi o do Banco de Pregos. Talvez por ser um aparato simples, sem muito detalhes, e envolver conceitos mais fáceis de serem compreendidos. Além do fato de poder se melhor percebido por meio do tato. Vejamos um exemplo:

E.1: O banco de prego a explicação é que como o espaço é muito grande não machuca né, os pregos não machucam, o peso distribui $[\ldots]$.

\subsection{Pós-Visita: Categoria C4 - Afetiva}

Nesta categoria, incluímos as lembranças dos objetos nas quais há a verbalização de uma carga afetiva que se sobressai sobre quaisquer tentativas de análise conceitual sobre o fenômeno apresentado.

\subsubsection{LEMBRANÇAS COM CARga AFETIVA (UNIDAdE DE ANÁLISE XI)}

Não por coincidência, os experimentos do Banco de Pregos, do Gerador de Van der Graff, e da Garrafa de Leyden, que foram os mais detalhados conceitualmente pelos visitantes, também foram os mais carregados de cargas afetivas em suas lembranças. Novamente, o entrelaçamento entre cognição e afetividade se faz presente. Vejamos uma fala:

E.1: Aquele lá do Van der Graff, você coloca a pessoa em cima da plataforma e o cabelo arrepia, a menina até brincou que as meninas podiam fazer nas pontas duplas, porque daí só sobe as pontas duplas, corta o cabelo mais barato.

\subsection{Pós-Visita: Metatexto - Afetividade, Cogniçáo e os Museus de Ciências}

Cada dia mais aumenta o questionamento do tradicional dualismo que trata afeto e cognição separadamente, como dimensôes isoláveis do funcionamento psicológico humano (ARANTES, 2003). Sobre essa temática, concordamos com o posicionamento de Piaget (2014, p. 37, grifo nosso) ao afirmar que:

[...] a afetividade interfere nas operações da inteligência, [...] ela as estimula ou as perturba, [...] é a causa de acelerações ou retardos no desenvolvimento intelectual, mas [...] não pode modificar as estruturas da inteligência como tais.

Em outras palavras, ainda continuando com Piaget (2014), embora não haja mecanismo cognitivo sem elementos afetivos e náo exista também um estado afetivo puro, sem elementos cognitivos, a afetividade "[...] não gera estruturas cognitivas e não modifica as estruturas no funcionamento das quais intervém" (PIAGET, 2014, p. 43). 
Desse modo, os museus de ciências desempenham um papel muito importante para despertar no seu público o interesse e a vontade para aprenderem determinado assunto. Mas, para que isso aconteça, a experiência museal tem que ser agradável, senão o efeito será o contrário do que se espera.

Também é de se esperar que haja uma compreensão maior dos fenômenos apresentados nos experimentos que despertam uma maior carga afetiva nos visitantes. Assim, ao colocarmos um depoimento referentes à compreensão conceitual seguido daqueles com lembrança mais carregada de carga efetiva, encontraremos algo do tipo: [...] o banco de prego a explicação é que como o espaço é muito grande não machuca né, os pregos não machucam, o peso distribui [...] I [...] O mais legal foi o banco de pregos [...].

Por consequência, quando o visitante se sente acolhido de uma maneira afetivamente agradável, além de ter uma maior possibilidade de compreender os conceitos explicados, naturalmente ele terá uma experiência museal gratificante. Assim, ao ser indagado se gostou da visita, provavelmente responderá nos seguintes termos: [...] Satisfação de ter explicado tudo certinho e ter conseguido entender também, alegria de poder entender os conteúdos [...]; [...] o que eu senti foi calma, eu achei que seria mais agitada [...] Com a explicação dos alunos, a gente vê a Física mais simples agora né[...]; [...] superou as expectativas [...]; [...] foi uma coisa nova..., nova assim, eu nunca tinha visto na verdade, mas acho que foi muito legal, assim uma experiência nova. [...] surpresa acho, surpresa e fiquei muito animada [...]; [...] eu tinha uma expectativa acabei me surpreendendo com tanto de coisa tanto de experimento que tinha lá [...] com certeza passei a gostar mais [...]; [...] eu gostei de tudo [...]; [...] achei legal, vi coisas que eu nunca tinha visto. Foi fácil de entender [...].

\section{Conclusốes}

No início da pesquisa, acreditávamos que sem uma modificação adequada dos objetos expostos na sala de Física do Museu de Ciências de nossa instituição, não teria como a experiência museal dos visitantes com deficiência visual ser gratificante nesse ambiente. Essa suposição implícita foi reforçada quando verificamos que a maioria das pesquisas sobre a temática de inclusão desse perfil de público focava exatamente nos objetos.

No entanto, a pesquisa nos revelou que o mais importante é garantir que o processo comunicativo entre o monitor e o visitante com deficiência visual seja efetivo. Isso não implica, necessariamente, em fazer qualquer tipo de mudança em boa parte dos experimentos. No nosso caso, por exemplo, ficamos surpresos com os resultados que tivemos fazendo apenas uma pequena preparação dos monitores antes da visita. Não foram feitas discussões teóricas profundas com eles sobre o tema da inclusão, somente refletimos sobre a importância de se fazer uma descriçáo detalhada dos aparatos, permitindo que os visitantes com deficiência visual tocassem os experimentos e tirassem as suas dúvidas. Esse procedimento mostrou-se na prática ser muito eficaz, permitindo que a experiência museal dos visitantes com deficiência visual na sala de Física do Museu de Ciências da Universidade Estadual de Maringá fosse afetivamente positiva, respondendo, desse modo, o nosso problema de pesquisa.

É claro que são bem-vindas quaisquer modificaçóes nos experimentos para facilitar o diálogo monitor-visitante, assim como a utilização de outros recursos táteis (escritos em braile; maquetes; placa em alto-relevo; etc). Mas isso não pode ser encarado como condição essencial 
para se começar a aceitar os visitantes com deficiência visual. Ao contrário, como primeira iniciativa para os Museus de Ciências que queiram incentivar a visita de pessoas com deficiência visual, recomendamos a execução de um minicurso com os monitores focando nas reflexões em como apresentar adequadamente os aparatos para esse perfil de público. Como referências teóricas básicas para os debates, sugerimos os livros de Soler (1999) e Camargo (2012). Apesar do objetivo desse último estar voltado para sala de aula, as suas consideraçóes também podem ser aproveitadas para o ambiente museal.

Terminamos essa pesquisa com muitas indagações ainda em mente. Gostaríamos de deixar registradas algumas delas como sugestóes para futuras pesquisas.

Qualquer aparato do ambiente de Física de um Museu de Ciências pode ser apresentado adequadamente para um visitante com deficiência visual?

Considerando que um aparato foi apresentado adequadamente para um visitante com deficiência visual, a sua compreensão dos conceitos físicos envolvidos, naquele aparato, é diferente de um visitante que enxerga?

Com relação à pergunta anterior, a reposta será a mesma para qualquer aparato, não importando se os conceitos envolvidos são da Mecânica, Óptica, Eletromagnetismo, Termodinâmica ou Física Moderna?

Quais aparatos do ambiente de Física de um Museu de Ciências podem ser apresentados adequadamente para um visitante com deficiência visual sem a utilização de um outro recurso tátil (escritos em braile; maquetes; placa em alto-relevo; etc), e quais dispensam esse apoio?

Esperamos que a nossa pesquisa tenha contribuído para a inclusão de pessoas com deficiência visual em Museus de Ciências, mostrando que tudo pode começar com pequenas iniciativas simples.

\section{REFERÊNCIAS}

ARANTES, V.A. (Org.). Afetividade na escola: alternativas teóricas e práticas. Summus: São Paulo, 2003.

BONI, V.; QUARESMA, S.J. Aprendendo a entrevistar: como fazer entrevistas em Ciências Sociais. Revista Eletrônica dos Pós-Graduandos em Sociologia Politica da UFSC. Florianópolis, v.2, n.1, p.68-80, 2005.

CAMARGO, E. P. de. Saberes docentes para a inclusão do aluno com deficiência visual em aulas de física. São Paulo: Editora Unesp, 2012.

DICKMAN, A. G.; FERREIRA, A. C. Ensino e aprendizagem de física a estudantes com deficiência visual: desafios e perspectivas. Revista Brasileira de Pesquisa em Educação em Ciências. v.8, n.2, 2008.

MARCONI, M. de A.; LAKATOS, E. M. Técnicas de pesquisa. São Paulo: Editora Atlas S.A, 2007.

MORAES, R; GALIAZZI, M.C. Análise textual discursiva. Unijuí: Ijuí, 2011

MORAES, R. Uma tempestade de luz: a compreensão possibilitada pela análise textual discursiva.

Ciência \& Educação. v.9, n.2, p.191-211, 2003. 
MORAIS, E. H. M. de; MAIA, E. J. P. ; PINTO; V. P. dos S . A experiência das visitas a exposição de longa duração do Museu de Ciências da Terra Alexis Dorofeef. In: ENCONTRO NACIONAL DOS GEÓGRAFOS - ENG, 16., Viçosa, 2010. Anais eletrônicos... Porto Alegre, 2010.

PIAGET, J. Relaçóes entre a afetividade e a inteligência no desenvolvimento mental da criança. Rio de Janeiro, Wak Editora, 2014.

POKER, R.B.; NAVEGA, M.T.; PETITTO, S. (Org.). A acessibilidade na escola inclusiva: tecnologias, recursos e o Atendimento Educacional Especializado. Marília: Oficina Universitária; São Paulo: Cultura Acadêmica, 2012.

SAMPAIO, R.L. Tecnologias digitais da informação e comunicação e aprendizagem curricular em museus: um estudo na cidade de São Paulo. 2014. 173f. Tese (Doutor em Educação) - Pontifícia Universidade Católica de São Paulo, São Paulo, 2014.

SAPIRAS, A. Aprendizagem em Museus: uma análise das visitas escolares no museu Biológico do Instituto Butantan. 2007. 154f. Dissertação (Mestrado em Educação) - Faculdade de Educação da Universidade de São Paulo. São Paulo, 2007.

SOUZA, V.M. de; SILVA, A.M.M. da. A experiência museal sob a perspectiva do modelo contextual de aprendizagem: uma compreensão a partir das memórias de longo prazo dos visitantes. Indagatio Didactica, v.8, n.2, p.78-93, 2016.

SOLER, M.A. Didáctica multissensorial de las ciencias: un nuevo método para alumnos ciegos, deficientes visuales, y también sin problemas de visión. Barcelona: 1999. Ediciones Paidós Ibérica.

TATO, A.L. Material de equacionamento tátil para usuários do sistema Braille, 2009. 84f. Dissertação (Mestrado) - Centro Federal de Educação Tecnológica "Celso Suckow da Fonseca” (Cefet/RJ). Rio de Janeiro, 2009.

Recebido em: 29/04/2017

Reformulado em: 14/09/2017

Aprovado em: 15/09/2017 
GRANDI, S.C. \& GOMES, L.C. 